\title{
DOI https://doi.org/10.36059/978-966-397-241-1-25
}

\author{
Шахрай В. М. \\ доктор педагогічних наук, доцент, \\ завідувач лабораторії інституційного виховання \\ Інститут проблем виховання \\ Національної академії педагогічних наук України \\ м. Київ
}

\section{ОРГАНІЗАЦІЯ ТЕАТРАЛЬНО-ІГРОВОЇ ДІЯЛЬНОСТІ ШКОЛЯРІВ З МЕТОЮ РОЗВИТКУ ЇХНЬОЇ СОЦІАЛЬНОЇ КОМПЕТЕНТНОСТІ}

Акцентується увага на значущості формування соціальної компетентності особистості в сучасних соціокультурних умовах. Розкривається сутність соціальної компетентності та визначається ї̈ структура (статусно-рольовий, ціннісно-диспозиційний та комунікативний компоненти). Наголошується на необхідності формування соціальної компетентності учнів підліткового та старшого шкільного віку, що зумовлено їхніми соціально-психологічними особливостями. Аналізується потенціал театрального мистецтва у формуванні соціальної компетентності особистості, зокрема розглядаються театрально-педагогічні інструменти та театрально-ігрові методи. З'ясовуються основні напрями організації театрально-ігрової діяльності школярів в закладі загальної середньої освіти (підготовка учнями спектаклів та театралізованих заходів; соціально-центрований театр; використання театрально-ігрових методів у процесі вивчення навчальних дисциплін; включення у театрально-ігрову діяльність дітей з виявами соціальної дезадаптації). Наводяться приклади організації театрально-ігрової діяльності підлітків та старшокласників, що спрямована на формування різних аспектів їхньої соціальної компетентності. Висвітлюються результати експериментальної роботи з формування соціальної компетентності школярів засобами театрального мистецтва, зокрема наголошується на засвоєнні підлітками та старшокласниками цінностей, розвитку їхніх вмінь працювати в групі, збагаченні мовленнєвої культури учнів. 


\section{Вступ}

Теперішнє суспільство із різновекторними соціальними зв'язками стає повсякчас складнішим, а це зумовлює наявність у його членів грунтовних знань для розуміння суспільних процесів, належних умінь для налагодження продуктивних соціальних взаємин, способів досягнення самореалізації. При цьому важливою $є$ гармонія між особистістю та суспільством, засвоєння його членами соціальних цінностей. Цю здатність індивіда встановлювати різнобічні, ефективні зв'язки із соціальним світом, який знаходиться в постійних змінах, можна назвати соціальною компетентністю.

Сучасні соціокультурні, економічні трансформації вимагають від кожного індивіда бути соціально компетентним, щоб можна було впоратися з ризиками, що продукує нинішній соціум. Водночас, соціальна компетентність особистості є умовою її власного розвитку та покращення довколишнього соціального простору.

Отже, постає завдання формування соціальної компетентності молодого покоління та пошуку результативних способів та засобів соціально-виховної дії на дітей та молодь, залучення школярів до видів діяльності, що гармонізують їхні взаємини 3 іншими, розширюють соціально-культурний досвід, активізують творчі задатки, заразом забезпечуючи емоційно-психологічне відновлення.

Вагомим способом пізнання людьми соціального і природного світу, усвідомлення ними ціннісної основи життєдіяльності, вияву емоцій, почуттів, розвитку комунікативних здібностей у всі часи було мистецтво, зокрема театральне. Вважаємо, що використання можливостей, механізмів театрального мистецтва у формуванні соціальної компетентності школярів у період підвищеної суспільної складності та соціально-психологічної напруженості $\epsilon$ доволі актуальним. Театральне мистецтво грунтується, насамперед, на сценічній грі, яка близька до природної ігрової діяльності дітей, що робить це мистецтво важливим виховним засобом, зокрема щодо соціального становлення учнів та формування їхньої соціальної компетентності.

\section{1. Основна частина. Сутність соціальної компетентності особистості та важливість їі формування в учнів підліткового та старшого шкільного віку}

Ми характеризуємо поняття соціальної компетентності особистості як цілісне інтегративне особистісне утворення, як сукупність соціальних знань, умінь, цінностей, досвіду, що забезпечують 
гармонійну взаємодію людини і суспільства (насамперед шляхом засвоєння провідних соціальних ролей, ефективного вирішення соціально проблемних ситуацій), самореалізацію та соціальну творчість, відображаючи якісний ступінь соціалізованості індивіда [32; 33]. Вважаємо необхідним 3'ясування структури та ознак соціальної компетентності особистості.

Для визначення структури соціальної компетентності особистості ми опирались передусім на статусно-рольову теорію, яка трактує роль як соціальну функцію особи, реалізація якої сприяє належному функціонуванню суспільства та гармонізації взаємин «індивід суспільство», «індивід - група», «індивід - індивід». Тому першим структурним компонентом соціальної компетентності особистості нами визначено статусно-рольовий, який свідчить про здатність індивіда до відповідної статусно-рольової поведінки, оволодіння новими соціальними ролями. Слід наголосити, що суспільство повинно бути зацікавленим в тому, щоб його члени, насамперед діти та молодь, належно опановували, виконували і збагачували соціальні ролі згідно з вимогами та викликами соціального життя.

На важливість оволодіння особистістю новими ролями вказує Г. Лейтц, наголошуючи, що в процесі засвоєння ролей, які стають дедалі більше диференційованими, людина розвиває саму себе [15, с. 102-103]. Дослідниця переконана в спроможності людини завдяки виконуваним ролям досягати самоактуалізації й змінювати світ та умови, що впливають на сутність ії особистості та вчинки $[15$, c. 23].

Слід також вказати на зв'язок соціальної ролі та ідеї, підтримуваної рядом вчених (Е. Гофман, І. Кон, Д. Маєрс та ін.), особливого «соціального театру», до якого залучена кожна людина, що зумовлює необхідність для неї постійно змінювати «рольові маски» відповідно до певної ситуації та норм. А тому соціальні досягнення особистості залежать, значною мірою, від іiі здатності мати акторську уяву, володіти майстерністю, що $\epsilon$ близькою до майстерності акторів [3, с. 168-169; 4, с. 305;].

Відомий дослідник П. Бергер зазначає, що «суспільство розписує ролі всім dramatis personae» і людина грає драматичні ролі в грандіозній п'єсі суспільства, і її соціальна значущість вимірюється числом ролей, які вона вміє грати, а весь життєвий шлях людини це «безперервна послідовність театральних вистав, що розігруються перед різними аудиторіями» [6, c.534]. Важливим $\epsilon$ судження Д. Маєрса про те, що «соціальне життя подібне до театрального 
дійства $з$ усіма його атрибутами на зразок сценаріїв, масок i декорацій» [18, c. 224]. На думку I. Кона, гра актора може бути моделлю (хоч і своєрідною та огрубленою) процесу засвоєння соціальних ролей [12, с. 179].

Твердження науковців про багатоаспектність зв'язку соціальних ролей та театру дають можливість зробити висновок, що з метою соціального розвитку школярів та становлення їхньої соціальної компетентності доцільно використовувати засоби та механізми театрального мистецтва, що допоможе розширити рольовий репертуар учнів, покращить осмислення ними сутності соціальних ролей.

Варто зауважити, що розвиток статусно-рольового компонента соціальної компетентності школярів потребує використання можливостей референтної для них соціальної групи. Такою групою для учнів $\epsilon$ насамперед шкільний колектив (зокрема театральний колектив) та ровесники.

Особливості реалізації соціальної ролі залежать насамперед від мотиваційно-смислової сфери індивіда, яку різні автори висвітлюють через такі поняття, як диспозиція особистості, потреби, інтереси, цінності, соціальні стратегії, життєві цілі тощо. Тому ми виокремлюємо, поряд із соціально-рольовим, ціннісно-диспозиційний компонент соціальної компетентності індивіда (включає цінності, потреби, інтереси, настанови особи). В основі ціннісно-диспозиційного компонента соціальної компетентності особистості постають цінності як провідний регулятор соціальної поведінки. Здійснення соціальної ролі буде суспільно значимим, якщо вона поєднується 3 духовними i моральними цінностями. Можна прогнозувати, що без опори на цінності людина лише удає належне виконання соціальної ролі.

Тому слід підтримати позицію І. Беха щодо важливості засвоєння дітьми та молоддю духовно-моральних цінностей. Відомий вчений зазначає, що ієрархія особистісних цінностей і смислів не дозволяє особистості розчинитися в емпіричному бутті, втратити сутнісні потенції, і водночас дає їй можливість діяти вільно, свідомо, цілеспрямовано [7, с. 23].

Д. Леонтьєв визначає три форми існування цінностей: 1) суспільні ідеали - вироблені суспільною свідомістю і наявні в ній узагальнені уявлення про досконалість у різних сферах суспільного життя; 2) предметне втілення цих ідеалів у діяннях або творах конкретних людей; 3) мотиваційні структури особистості («моделі належного»), 
які спонукають їі до предметного втілення в своїй поведінці та діяльності суспільних ідеалів. Соціальні цінності, на думку вченого, виконують роль сполучної ланки між поведінкою особистості, 3 одного боку, й соціальними групами, спільнотами та суспільством з іншого, і особистісні цінності $є$ генетично похідними від цінностей соціальних груп [16].

Переконані, що розвиток ціннісно-диспозиційного аспекту соціальної компетентності повинен здійснюватися у взаємозумовленості зі статусно-рольовим, адже засвоєні особистістю цінності $€$ важливим чинником вибору статусів та соціальних ролей.

Характеристикою соціально компетентної особистості є також її здатність до продуктивного спілкування, належної комунікації $[10$, c.7]. Спілкування $€$ важливим інструментом для здійснення зрілої статусно-рольової поведінки та засвоєння соціальних цінностей. Тому окремі дослідники соціальну компетентність особистості розуміють передусім як розвиненість в індивіда комунікативних умінь та навичок, які сприяють плідній груповій роботі, або ж вони допускають, що комунікативна компетентність особистості є складником соціальної [29].

Базуючись на таких підходах, ще одним компонентом соціальної компетентності особистості варто визнати комунікативний. При цьому ми спираємось, зокрема, на твердження Л. Орбан-Лембрик, що в основі соціально-психологічного розуміння особистості знаходиться їі комунікативний потенціал, комунікативний світ особистості, який спричинює соціально-психологічне відображення реального соціуму, обмін інформацією, вміннями, цінностями, нормами [22, с. 129].

До комунікативного компонента соціальної компетентності особистості відносимо: розвиненість соціального інтелекту; уміння повноцінного спілкування в групі (зокрема вміння здійснювати належну самопрезентацію); готовність та здатність до розв'язання чи відвернення конфліктів; достатній рівень мовленнєвої культури; розвиненість чи сформованість інтерактивних умінь для успішної взаємодії в конкретних соціальних ситуаціях (вміння аналізувати ситуацію, створювати умови для співробітництва 3 певними людьми) тощо.

Узагальнюючи викладене вище, у структуру соціальної компетентності індивіда включаємо статусно-рольовий компонент (формується під впливом вимог суспільства), ціннісно-диспозиційний (формується шляхом інтеріоризації соціальних цінностей, норм у 
внутрішню сферу особистості) та комунікативний, який відображає способи соціальної взаємодії індивіда, які допомагають виконанню соціальних ролей та утвердженню соціальних цінностей.

Формування соціальної компетентності школярів передбачає врахування соціально-психологічного розвитку учнів, основних підходів до сучасної виховної діяльності, визначення ефективних засобів формування у юного покоління соціальної компетентності.

Сучасні підлітки мають два основних вектори особистісного розвитку: 1) прагнення до освоєння та оволодіння всім діапазоном соціального простору; 2) прагнення до рефлексії свого внутрішнього інтимного світу (через самозаглиблення і відсторонення від однолітків, близьких, усього макросоціуму) [20, с. 418-419]. В. Мухіна вказує, що діти старшого підліткового віку прагнуть утвердити себе в лідерстві, розвивати в собі почуття відповідальності за себе і за інших, робити самостійний вибір у звичайному житті, в екстремальних ситуаціях, бути готовими до реалізації громадянського вибору. Водночас соціальна ситуація становлення підлітків в останні часи суттєво ускладнилася, зокрема через стрімке поширення Інтернету та комп'ютерних технологій, що знизило стійкість контактів підлітків 3 іншими людьми, послабило прив'язаність дітей до конкретної групи, компанії. Це породжує нові комунікативні особливості підлітків: завдяки використанню чатів, соціальних мереж у них краще розвивається вербальна комунікація, водночас навички невербальної комунікації та емоційного обміну суттєво знижуються [31]. Також негативними чинниками соціального розвитку підлітків $\epsilon$ зростання соціальної напруженості, невпевненість підлітка у власних силах, посилення відчуження в сім'ї та конфліктності між батьками й дітьми [31].

У старшому шкільному віці свідомість учня $\epsilon$ особливо сприйнятливою, здатною переробляти і засвоювати величезний потік інформації. У цьому віковому періоді розвиваються критичність мислення, прагнення дати власну оцінку різним явищам, аргументувати свої твердження. Водночас ще зберігаються настанови і стереотипи, властиві підліткові. Тому у поведінці учнівської молоді спостерігається дивне поєднання суперечливих якостей і рис: прагнення до ідентифікації і до відокремлення, конформізм і негативізм, наслідування соціальним нормам і їх заперечення, прагнення до спілкування і втеча від зовнішнього світу, відчуженість від нього. Нестійкість і суперечливість молодіжної свідомості може стати основою для вияву різних 
поведінкових девіацій. У роботі зі старшокласниками необхідно враховувати невисокий рівень їхньої соціальної практики, нестачу «досвіду реального практичного і духовного життя» [20, с. 420].

Наголошуючи на важливості соціального становлення дітей у підлітковому та старшому шкільному віці, Р. Немов зазначає, що «багато чого із того, що людина як особистість набуває в шкільні роки, залишається 3 нею на все життя і значною мірою визначає їі буття» $[21$, с. 246].

Отже, соціально-психологічні особливості підлітків та старшокласників є основою формування соціальної компетентності, яка стане підвалиною соціальної успішності молодих людей та гарантією уникнення ними різних поведінкових девіацій, що можуть гальмувати повноцінну реалізацію учнівської молоді в соціумі.

У процесі формування соціальної компетентності школярів доцільно, на нашу думку, брати до уваги пріоритети сучасного виховання. Це, насамперед, орієнтація на потреби й перспективи розвитку суспільства, підготовка молоді до майбутнього життя, що навчає юних бути спроможними до групової діяльності, розробляти життєві плани, засвоювати навички роботи в сучасних організаційних структурах. Важливим є дотримання балансу між індивідуально-особистісним розвитком учнів та спрямуванням їх до соціальної взаємодії, усвідомлення суспільних потреб, адже акцентування уваги насамперед на особистісному зростанні й досягненнях школярів може призводити до ігнорування ними інтересів соціуму, розвитку егоїзму у ставленні до інших. У виховній роботі 3 підлітками та старшокласниками слід, передусім, застосовувати не вербальні методи, а методи та засоби діяльніснопрактичного характеру, які сприяють глибшому пізнанню школярами життєвих реалій, визначенню своїх життєвих планів.

Переконані, що ефективним засобом формування соціальної компетентності, профілактики соціально-поведінкових відхилень $\epsilon$ театральне мистецтво. Вважаємо правильним підхід О. Богданової, яка наголошує на важливості використання театральних занять також у роботі і з неблагополучними дітьми, наголошуючи на тому, що ці заняття сприяють розвиткові в них позитивної самооцінки, що допомагатиме їм зайняти гідне місце у житті $[8$, c. 65]. Тому доцільно розкрити потенціал театрального мистецтва у формуванні соціальної компетентності школярів. 


\section{2. Можливості театрального мистецтва у формуванні соціальної компетентності школярів та особливості організації театрально-ігрової діяльності учнів підліткового та старшого шкільного віку}

Дослідники зазначають, що театр має певну подібність до реальних соціальних процесів, він відображає грунтовний людський досвід щодо шляхів згуртування людей, а тому театр повинен допомагати людям вирішувати проблеми, що виникають під дією сучасної цивілізації [2, с. 25-29; 9, с. 89-90]. Важливою є думка 0. Лапіної, яка значення театру бачить в його здатності вводити людей у світ життєво важливих ідей і цінностей [14, с. 22].

Особливостями театрального мистецтва, що зумовлюють не тільки естетичну його функцію, а й соціальну (соціальнокомунікативну, соціально-рольову тощо), можна назвати такі.

1. Це, передусім, синтетична природа театру (театральні твори (спектаклі) включають інші види мистецтва, зокрема літературу, музику, образотворче мистецтво, вокал, хореографію тощо, що поєднуються в образі вистави).

2. Ознакою театрального мистецтва $\epsilon$ також колективний характер творчого процесу. Тут можна говорити як про спільну творчість колективу театру, так і про різнобічну взаємодію (наприклад, з глядачами).

3. Театр має в своїй основі мистецтво гри. Акторська гра $\epsilon$ складним і цікавим явищем, що допомагає глядачеві сприйняти i осмислити сутність сценічного дійства. Слід наголосити, що в акторській грі та грі дитячій є схожості й відмінності [5]. Схожими $\epsilon$ механізми гри: як дитяча, так і сценічна гра вимагає роботи уяви i фантазії; обов'язковою умовою $є$ віра в запропоновані обставини; наявність емоційного переживання тощо. Основні відмінності: дитяча гра $є$ природною і спонтанною, а сценічна - спеціально організованою; дитина в грі переживає особисті почуття, а актор - почуття персонажа тощо. Насамперед ігровий характер театрального мистецтва, на нашу думку, зумовлює доцільність його використання у роботі зі школярами, зокрема для естетичного та соціального розвитку дітей.

4. Важливою $\epsilon$ «реактивність» театрального мистецтва, тобто його здатність сприймати і відтворювати зміни, що відбуваються в суспільстві, а це робить театр важливим соціальним та виховним чинником.

Можемо стверджувати, що театральне мистецтво виконує як художньо-естетичну, так і різнобічну позаестетичну функцію. 
Теоретик мистецтва Г. Шпет говорить про це так: «Ми б звузили значення театру, як мистецтва, якби обмежили його вплив на глядача тільки естетичним ефектом, - може бути, що ніяке інше мистецтво не привносить з собою в художнє враження стільки позаестетичних моментів, як театр» [34]. Важливою $€$ думка дослідниці О. Коханої, яка в праці «Соціокультурні функції дитячого та молодіжного театру» наголошує та тому, що театр може допомогти сучасним дітям і молоді визначити життєву модель, посприяти становленню самостійно мислячої, активної, соціально адекватної особистості [13].

Театральне мистецтво здійснює свій соціально-виховний вплив на дітей та молодь завдяки естетико-педагогічним інструментам. До них ми відносимо: 1) театральну гру, яка дає можливість через канали перевтілення та ігрової свободи засвоювати розмаїтий спектр соціальних ролей, удосконалювати свою особистість; 2) театральну групу (колектив) як педагогічно створене соціальне середовище, модель сприятливого соціуму, де дитина апробує, оцінює варіанти соціальної взаємодії; 3) драматичний складник театральних дійств (завдяки його якості та змістовності), що робить можливим залучення школярів до загальнолюдських, соціальних цінностей, удосконалення їхнього розуміння соціуму, складних зв'язків, що його пронизують; 4) організаційно-методичну систему підготовки театральних постановок; 5) комплекс різних видів мистецтва, що використовуються у театральних спектаклях і посилюють його емоційно-почуттєвий вплив на учнів, сприяючи збагаченню їхніх міжособистісних взаємин, осягненню ними цілісності довколишнього світу, усвідомленню його гармонії [33, с. 122].

Потенціал театрального мистецтва виявляється й у використанні під час організації театрально-ігрової діяльності учнів значного числа методів. Ми їх поділяємо на групи: 1. Загальнопедагогічні (використовуються при педагогічному регулюванні різних видів дитячої діяльності, зокрема й театрально-ігрової) - бесіда, дискусія, метод прикладу, метод громадської думки, заохочення та ін. 2. Методи навчання театральної гри: метод акторського (психофізичного) тренінгу (вправи на розвиток уваги, уяви, пам'яті, на м'язове розслаблення); етюдний метод; метод фізичних дій; метод логічного аналізу; метод театрального показу; метод створення біографій персонажів вистави; метод творчого самовираження; метод розвитку сценічної мови. 3. Організаційно- 
театральні методи (стимулювання сценічного і позасценічного спілкування, розподіл ролей, організація показів спектаклів).

Правила використання загальнопедагогічних методів у діяльності дитячих театральних колективів не відрізняються від інших сфер їх застосування. Насамперед виокремлюємо універсальний метод бесіди, що може бути задіяний під час обговорення драматичних творів, ознайомлення 3 життям і творчістю їхніх авторів, i спрямований на 3'ясування ступеня впливу ідей творів на сучасну молодь, можливості їх утілення в реаліях сьогодення тощо.

Важливим є метод дискусії, адже за його застосування в дітей розвиваються здатність переконувати інших, толерантні взаємини, культура спілкування тощо. Метод дискусії застосовується під час обговорення персонажів п'єс, їхніх життєвих позицій, з'ясування можливості рівнятися на сценічних героїв у сучасному реальному житті тощо.

Метод прикладу полягає в чіткому демонструванні організатором дитячої театрально-ігрової діяльності власних ціннісних орієнтацій та ідеалів, зосередженні уваги дітей на взірцях соціальної поведінки як персонажів п'єс, так і реальних осіб.

Не слід уникати організаторам театрально-ігрової діяльності методу заохочення, використання слів підтримки, схвалення, що сприяють комфортній атмосфері творчого самовираження дітей.

Предметом належної педагогічної уваги мають бути методи другої групи - методи навчання (сприяння) театральній грі, зокрема метод акторського тренінгу, який розуміється насамперед як необхідний засіб підготовки актора до успішної сценічної професійної діяльності. Ми переконані, що в театральному колективі, в якому грають школярі, потрібно використовувати елементи акторського тренінгу, адже він налаштовує на сценічну гру, піднімає настрій, сприяє появі відчуття свободи, розкутості й упевненості.

Одним з основним елементів акторського тренінгу є вправи для зняття тілесного напруження, адже скута людина не може ні думати, ні відчувати. Уміння довільно розслаблювати м'язи дає поштовх творчій активності та свободі юного актора. А психологічна й фізична розкутість дитини сприяє також іï ефективному соціальному функціонуванню.

Варто також приділити увагу іншим складникам акторського тренінгу - вправам на розвиток уваги, уяви та емоційної пам'яті, які, на думку К.Станіславського, $\epsilon$ неодмінними для повноцінної творчості актора [28, с. 112-177]. 
Вправи на розвиток уваги допомагають скеровувати ії й зосереджувати на певному об'єкті. Це особливо важливо за нинішніх умов, коли надмірно страждає концентрація уваги дитини через захоплення нею телепередачами, що потребують активності лише мимовільної уваги. Також слід зазначити, що сучасні діти формуються в умовах безперервного потоку різноликої інформації, що надходить звідусіль, породжуючи звичку поверхового сприйняття й призводячи до надання переваги дитиною малозмістовній культурній продукції [27, с. 198].

Отже, слід констатувати, що театральна самодіяльність має значні можливості для соціального розвитку школярів і досягнення його якісного рівня - соціальної компетентності. Підтримуємо висловлювання театрального педагога В. Розентуллера про значущість організації самодіяльного театру в школі, який наголошує, що немає іншого, крім театру, мистецтва, яке настільки сильно потребувало б соціальних здібностей, соціального чуття, розвивало їх, адже будьяка постановка можлива лише за наявності єдиного ансамблю виконавців, що поєднані довірою, терпінням, добротою [30, с. 8].

Які ж основні види організації театрально-ігрової діяльності учнів можна виділити в закладі освіти? При цьому театрально-ігрову діяльність школярів ми розуміємо як їхню активність, в основі якої програвання учнями театральних ролей та залучення їх до різних видів театралізації, що не передбачає оволодіння навичками професійного актора.

Насамперед важливою є організація театрально-ігрової діяльності учнів шляхом підготовки спектаклів за драматичними творами, літературними композиціями, проведення вечорів, свят 3 театральними компонентами тощо. Використання театральноігрової діяльності школярів 3 акцентуванням на іiі соціальнокомпетентнісному потенціалі вимагає значної уваги до ії змістової наповненості, що знаходить вияв насамперед у репертуарному (драматичному) матеріалі. Добираючи драматичний матеріал для постановок, не треба намагатися приховати від юної особистості правду сучасних життєвих реалій, які далеко не завжди $\epsilon$ безхмарними. Водночас не слід підкріплювати в підлітків та учнівської молоді настрої апатії, безнадії, а спрямовувати їх на усвідомлення та розв'язання серйозних життєвих питань. На жаль, у літературі, зокрема українській, драматичних творів для організації театрально-ігрової діяльності школярів, найперше підлітків, украй мало. 
Можна запропонувати такі репертуарні твори для учнів різних класів. У 5 класі доцільно організувати театралізовані календарнообрядові свята - «Різдвяна палітра», «Ой весна, весна, днем красна», здійснити постановку п'єси «Коли зійде місяць» (Н. Забіла). У 6 класі цікавими репертуарними творами стануть: «Напровесні» (О. Олесь), «Зимове дійство» (В. Вовк), «Про Андрійка і Терпця» (Г. Бойко). Для школярів 7-ого класу творами для постановок можуть бути «Сюрприз» (В.Бойко); «Солом'яний бичок» (О.Олесь). 3 дітьми 8-9-х класів пропонуємо здійснювати інсценізацію уривків літературних творів: «Маруся Чурай» Л. Костенко, «Кочубеївна» $\mathrm{X}$. Алчевської, постановку драматичних творів (чи їх уривків, скорочених варіантів): «Синього птаха» М. Метерлінка, п’єс В. Вовк, Б. Стельмаха та ін. Також можуть бути використані такі твори, як «Микита Кожум'яка» (О. Олесь); «Про хлопчика Клаповушка і дуже доброго чарівника» (В. Бойко); «Бояриня» (Леся Українка); «Злидні» (О. Олесь).

У 10-11-х класах можливе звернення до більш складного матеріалу - п’єс М. Гоголя, I. Карпенка-Карого, I. Кочерги, Е. Ростана, М. Старицького, В. Шекспіра, сучасних драматургів. Корисними для учнів будуть постановки за творами: «По дорозі в казку» (О. Олесь); «Іконостас України» (В. Вовк); «Король Лір» - уривки (В. Шекспір). Цікавим для учнів старшого шкільного віку стане проведення театралізованого конкурсу «Жіночі вершини: поетичний образ української жінки» (за творами Л. Костенко, І. Кочерги, Х. Алчевської та ін.).

Учні 10-11-х класів частіше замислюються про майбутнє доросле життя, тож для цього вікового контингенту доречними будуть твори, що порушують питання дружби, кохання, соціальної відповідальності. Педагогічно доцільно готувати постановки й на основі власних творів членів театрального колективу, до написання яких школярів, особливо старших класів, потрібно заохочувати.

Репертуар дитячого театрального колективу має формуватися 3 творів, що висвітлюють людське життя в усіх барвах - як темних, так і світлих, розкривати різноманітні соціальні ролі, без яких не може функціонувати соціум: громадянина, патріота рідної землі, героя, члена сім'ї (батька, матері, сина, дочки, брата, сестри), вірного друга (подруги), трудівника тощо.

Вагомий потенціал щодо формування соціальної компетентності школярів має такий сучасний вид театральної самодіяльної творчості, як соціальний театр [23; 26], що вирішує завдання 
розширення знань учнів та молоді про актуальні соціальні процеси та проблеми, спрямовує на обговорення й осмислення питань, що $€$ найбільш дотичними до життєвих потреб, інтересів підлітків та учнівської молоді, сприяє активізації соціальної взаємодії школярів, розвитку їхнього соціального мислення, виробленню соціальноповедінкових навичок та вмінь передбачати різноманітні соціальні ризики й уникати їх.

Підгрунтям для використання театрального мистецтва 3 його соціальною та профілактичною спрямованістю в освітньому процесі школи $є$ ідеї видатних мислителів XX століття - Б. Брехта, Я. Морено, А. Боаля та ін.

Беручи до уваги означені вище ідеї та підходи до використання театрального мистецтва і акцентуючи увагу на соціальному театрі як виді естетичної творчості, пропонуємо введення в соціальнопедагогічну практику загальноосвітньої школи соціальноцентрованого театру як театру широкої функціональності (від соціально-орієнтаційної до терапевтичної) та масштабності (від змалювання й актуалізації проблем як суспільства в цілому, так і групових проблем, насамперед підліткових, молодіжних).

Одним із його видів $\epsilon$ інтерактивний театр, основою якого $\epsilon$ діалог: акторів, режисерів, драматургів через театральну постановку 3 глядачами, між акторами, між самими глядачами, а також переведення глядача з позиції спостерігача (сприймаючого) в позицію більш активну, в позицію «глядач-актор», що створює ширші можливості для зміни як власної особистості, так i навколишнього світу.

Переконані в доцільності функціонування в закладах загальної середньої освіти інтерактивного театру, який поєднує театральне дійство і безпосередній діалог, розмову з присутніми на ньому глядачами про важливі життєві питання, що порушуються у виставі, спонукання всіх учасників до роботи думки, формування власних оцінок та висновків.

Інтерактивний театр $€$ одним із тих різновидів театру, що, спираючись на свою нестандартність, високу емоційність, відсутність прямого моралізування, може досить активно залучати молодь до обговорення проблем, до пошуку відповідей на хвилюючі питання, визначення свого життєвого вибору, сприяти перетворенню підлітків і старшокласників із об'єктів виховного процесу в активних учасників соціалізації власної особистості. Важливість інтерактивного театру посилюється в сучасних соціально- 
педагогічних умовах, коли вербальні методи виховання не можуть конкурувати 3 яскравістю, образністю телебачення, обсягами та швидкістю отримання інформації через Інтернет. Слушною $є$ думка I. Сергієнко про те, що сучасні підлітки пересичені образною інформацією, яка надходить від телепередач, відеофільмів, комп'ютерних ігор, а тому «форми і методи, що привернули б увагу молодої людини, мають бути незвичними для підлітка, щоб викликати живий інтерес» [25, с. 26].

В інтерактивному театрі не потрібна акторська підготовка більшої частини учасників, тому він $є$ надзвичайно мобільним, не забирає багато часу, не потребує спеціально підготовленої сцени й дорогих декорацій та костюмів. Його виступи можуть відбуватися на будь-якому майданчику (в класній кімнаті, на вулиці, в бібліотеці та ін.). У 10-11-х класах соціально-просвітницький театр грунтується на серйозній розмові зі старшокласниками про різні соціальні проблеми у форматі «за і проти». Вистава має включати досить суттєвий публіцистичний складник, надаючи учням важливу інформацію для обговорення та осмислення. Зразком організації соціально-просвітницького театру для старшокласників можуть стати «сократівські бесіди», метод діалогу як шлях пошуку істини.

Упродовж навчального року готується 4-6 «діалогів» (виставінтеракцій). Пропонуємо такі театралізовані «діалоги»: «Він і вона» (про взаємини між хлопцями й дівчатами); «Наркотики: омини»; «Цигарка: хто вона?»; «Куди веде дружба 3 алкоголем»; «Громадянином бути зобов’язаний»; «Ми і батьки»; «Закон один для всіх»; «У світі речей» (негативи споживацтва); «Творче дозвілля»; «Майбутня професія»; «Такий багатоликий людський світ» (про міжетнічні взаємини); «Насильство: слабкість чи сила?». Тематика театралізованих «діалогів» може бути набагато ширшою, залежно від зацікавлень самих школярів та творчої спроможності педагогів.

Також вважаємо доцільним використання театрально-ігрових методів і прийомів у процесі викладання навчальних дисциплін, адже належне засвоєння знань, насамперед із гуманітарних та суспільствознавчих предметів, $\epsilon$ основою соціального розвитку підлітків і старшокласників. Використання театральних засобів завдяки їх емоційно-образній дієвості сприяє міцнішому засвоєнню учнями знань, що робить для них зрозумілішою картину соціального світу. Роль театральної гри школярів у процесі навчання зростає в нинішній ситуації, коли в культурі формується новий тип раціональності, а «в організації розумових процесів зростає роль 
пізнавальної діяльності асоціативно-образного типу, механізмів інтуїції (інсайт)» [19, с. 5]. Це зумовлює необхідність більш широкого використання театрально-ігрових методів як у вихованні, так і навчанні.

Вважаємо доволі цінними для активізації театрально-ігрової діяльності школярів ідеї соціо-ігрової педагогіки (О. Єршова, В.Букатов), в основі яких - відхід на уроках від абстрактних педагогічних завдань і перенесення уваги на взаємодію, спілкування дітей між собою [11, с. 112-122].

Ми визначаємо найважливіші аспекти потенціалу театральної гри як засобу соціального розвитку учнів у процесі навчання: a) підвищення ступеня та якості засвоєння матеріалу шляхом його емоційно-почуттєвого освоєння; б) стимулювання розвитку інтересу до конкретних навчальних предметів та певних тем (проблем), завдяки яким педагог розширює знання учнів про навколишній соціум, розвиває їхнє соціальне мислення; в) удосконалення взаємин між учнями й вчителями, утвердження поваги та довіри школярів до педагогів; г) посилення соціально-рольової та соціальнокомунікативної функції навчальних предметів (за допомогою театральних засобів здійснюється розвиток навичок соціальної комунікації учнів - розширення їхнього лексичного запасу, оволодіння культурою, красою мовлення (інтонація, вимова, підтекст), становлення соціального інтелекту, вмінь працювати в групі); д) внесення у навчальний процес духу нестандартності, творчості.

Наприклад, у процесі вивчення навчальних дисциплін можна організувати театрально-ігрову діяльність школярів за творами: «Княжа Україна» (за поезіями О. Олеся) (історія України); «У театрі Давньої Греції», уривки із трагедії Есхіла «Прометей (всесвітня історія, мистецтво, зарубіжна література); «Слово про Ігорів похід» (за поезіями 0. Олеся) (історія України); «Сіркова Січ» (за поезією Л. Горлача) (історія України); «Твої листи завжди пахнуть зов'ялими трояндами» (за творами Лесі Українки) (українська література); інсценізація «Слави золота зоря», присвячена корифеям українського театру (за книгою М. Кагарлицького «Наодинці 3 совістю») (художня культура); «Антігона» (Софокл) (художня культура).

Слід вказати на значні можливості для розкриття проблем сучасного соціуму, вироблення у школярів сценаріїв соціальної поведінки сучасної літератури для дітей, насамперед української. 
Твори сучасної літератури корисно інсценізувати, щоб занурити сучасного учня в різні життєві колізії, що дасть можливість йому краще пізнавати сучасне соціальне життя 3 його проблемами, можливостями, ризиками.

Важливим є залучення до театрально-ігрової діяльності учнів із виявами соціальної дезадаптації. Постійні ризики, що стали характерними для сучасного соціуму і є особливо загрозливими для юної особистості, зумовлюють потребу в профілактиці й терапії соціальної дезадаптації дітей підліткового та старшого шкільного віку, адже саме в ці вікові періоди закладаються основи адекватної соціальної поведінки. Для подолання соціальної дезадаптації школярів необхідно використати можливості соціально здорового театрального колективу, який може стати для дітей бажаним середовищем спілкування [24].

Вважаємо, що театральний колектив за правильного педагогічного керівництва замінить дитині асоціальну групу, де вона знаходила самореалізацію й підтримку, водночас якої не змогла віднайти ні в школі, ні в сім'ї. На важливість терапевтичної групової роботи вказують А. Айхінгер та В. Холл, які впродовж багатьох років використовують драматичні техніки в роботі з дітьми з різними психологічними й соціальними проблемами. Вони зазначають, що група $\epsilon$ тією соціальною реальністю, яка «дає змогу розвинути соціальну компетентність і успішність» [1, с. 12].

Для роботи з учнями із виявами дезадаптації доречно використовувати всі види театрально-педагогічних технологій - від традиційних класичних, заснованих на кращих зразках світової й вітчизняної драматургії, до тих, що здійснюються на ідеях психодрами, драмотерапії, арт-терапії, маскотерапії тощо. Переконані, що залучення цієї категорії дітей до театральних занять, побудова комунікативних стосунків на толерантній основі з іншими членами театрального колективу, із педагогами сприятиме формуванню в них нових, більш конструктивних поглядів на навколишній соціум, виробленню нових моделей поведінки.

Педагогічно плідним $\epsilon$ використання театрально-педагогічних методів та прийомів у контексті утвердження ідей інклюзивної освіти, спрямованої на навчання й виховання дітей із функціональними обмеженнями разом зі здоровими. Спільна театрально-ігрова діяльність створює для дітей з функціональними обмеженнями емоційно сприятливе мікросередовище, сприяє розвитку їхньої здатності до належних міжособистісних взаємин, 
поліпшуючи в такий спосіб загальне психологічне самопочуття та сприяючи формуванню соціальної компетентності як цих дітей, так і їхніх здорових однолітків.

Театрально-ігрова діяльність, що містить елементи фізичного й соціально-психологічного тренінгу, активізує розумову діяльність дітей із функціональними обмеженнями, розвиває їхню уяву, творчі здібності, допомагає моделювати життєві ситуації, в яких вони зазвичай розгублюються, та вчить використовувати в них відповідні поведінкові тактики.

\section{3. Організація та результати експериментальної роботи} з формування соціальної компетентності школярів шляхом залучення їх театрально-ігрової діяльності

у процесі педагогічного експерименту виховна робота, побудована на театрально-ігровій діяльності школярів, спрямовувалась на розвиток трьох компонентів соціальної компетентності особистості - статусно-рольового, ціннісно-диспозиційного та комунікативного, що знаходили відображення у відповідних знаннях, емоціях, навичках, учинках школярів. Через театральну гру, залучаючись до різних форм позанавчальної та навчальної діяльності, учні краще усвідомлювали складність, неоднозначність соціального світу, розширювали знання про нього й набували умінь та навичок ефективної соціальної дії. Педагогічний акцент робився на таких провідних соціальних ролях сучасної особистості, як громадянин, трудівник (учень), член сім'ї, культурний споживача і творець у сфері дозвілля.

Наведемо окремі приклади організації театрально-ігрової діяльності школярів.

Соціально-рольовий спектр життя людини сучасного суспільства розкривався через зміст театральних постановок та систему методів театрально-педагогічної і соціально-виховної діяльності. Для розширення розуміння учнями сутності громадянськості, наближення їх до виконання соціальної ролі громадянина, здійснено підготовку та показ ряду театральних постановок. Робота над мініп'єсою «Який ти громадянин?» (7-ий клас) ставила перед собою завдання зміцнити в школярів усвідомлення того, що справжній громадянин - це не тільки гарні слова про свій народ, рідний край, Батьківщину (хоча це також важливо), але, насамперед, справи, спрямовані на допомогу іншим людям, своєму рідному місту (селу), довколишній природі тощо. Постановка міні-спектаклю стала 
частиною виховного заходу «Я - громадянин України». У процесі обговорення театральної постановки дітям ставилися запитання: «Яку б оцінку, як громадянину, ви б поставили Славку? Чи схожі ви інколи на цього героя? Які ознаки того, що Славко не є справжнім громадянином?» Дітям також було запропоновано прочитати прислів'я і приказки про любов до рідного краю, а потім визначити, які з них були найвлучнішими (ними стали такі народні вислови: «Де рідний край, там і рай»; «Кожному мила своя сторона»; «Як будеш різної землі триматися, то будеш від неї сили набиратися»; «Людина без рідної землі, як соловей без гнізда»; «Грудка рідної землі дорожча за золото»). Наприкінці заходу педагог порадив учням зініціювати такі справи, що свідчили б про громадянську позицію класу. Діти запропонували для цього підготовку вистави для учнів молодших класів, участь в озелененні класу та школи, підготовку подарунків (власними руками) ветеранам війни та праці та ін.

Значна увага приділялася профілактиці відхилень у соціальній поведінці школярів (тютюнокуріння, вживання алкоголю, протиправна поведінка тощо). Обов'язковим елементом підготовки та показу профілактичних спектаклів були бесіди про шкоду тютюну, алкоголю, виготовлення плакатів, малюнків. Перед показом спектаклю «Ріпка» педагог звертається до зали: «Всі ми знаємо народну казку «Ріпка». Вона розповідає про те, як дід, баба та інші герої намагались вирвати ріпку, але без допомоги мишки не могли 3 цією роботою справитись. А ми сьогодні у своїй невеликій виставі хочемо показати, чому ж ці герої виявилися безсилими. Ви ж після перегляду висловите свої думки з приводу цього». Після вистави проводилась бесіда з присутніми дітьми за такими запитаннями: «Чи знаєте ви випадки, коли спиртні напої погіршували здоров'я людей, не давали можливості справлятися зі справою, за яку вони бралися? Чи відомо вам про вживання алкоголю школярами? Скажіть, а чи варто себе наражати на небезпеку, адже можна втратити здоров'я, не здійснити свої мрії?». Педагог вивішує плакат, на якому чорними літерами написане слово «Алкоголь», роздає дітям невеличкі аркуші паперу і запитує: «Якими словами можна охарактеризувати слово «алкоголь»? (діти називають слова: важкий, темний, падати, кричати, сваритися, битися та ін.). Запишіть їх. Скажіть, ці слова вам подобаються? Ні? Я пропоную розірвати аркуші з цими словами і викинути у смітник». Замість плаката із словом «алкоголь» вчитель вішає плакат із словом «здоров'я», написаного яскравими літерами: «Алкоголю ми протиставляємо здоров'я. 
А якими словами ми можемо охарактеризувати здоров'я?» (відповіді дітей: сильний, радісний, веселий, перемагати та ін.).

Увага приділялася також розвитку комунікативної культури школярів, насамперед збагаченню лексичного запасу, емоційній виразності мовлення, його логіці, необхідності боротьби із забрудненням мови лайливими словами. На усвідомлення важливості володіння мовним багатством спрямовувалась театральна постановка «Світла душа», що стала складовою виховного заходу «Краса мови - це сьогодні важливо?». Старшокласники висловили своє ставлення до основної ідеї міні-п'єси - світла душа людини відображається насамперед у світлому слові. Більшість учнів погодилася з думкою героїні п'єси: «Однозначно - світла душа не може проявлятися у словах грубих, лайливих. Коли я їх чую, то здається, що вони перетворюються у клубки сірого важкого диму, які не дають дихати. Хочеться від них пошвидше відбігти». Із школярами проведена дискусія за такими запитаннями: «Чи може людина 3 низькою мовною культурою досягнути життєвого успіху?»; «Чи будете ви дружити з тими, хто лається?»; «Грубі слова - це ознака сили чи слабості?» та ін. Школярі у процесі дискусії приходили до думки, що повноцінне життя в сучасному соціумі вимагає значних зусиль кожної людини щодо оволодіння різними аспектами культури мови - розширення словникового запасу, збагачення мови фразеологізмами, образними порівняннями, правильною інтонацією, чіткою дикцією, контролем над мімікою, жестами, що супроводжують мовлення, тощо.

Коротко розкриємо результати організації театрально-ігрової діяльності школярів (окремо учнів молодшого підліткового віку, старшого підліткового віку і старшокласників).

Залучення дітей молодшого підліткового віку до театральноігрової діяльності та пов'язаної з нею соціально практичної, творчої роботи принесло помітні результати. В учнів розширилися знання про соціальні ролі, передусім про роль учня (трудівника) (необхідність здобувати знання, поважати працю інших), учасника культурного дозвілля (без тютюну, алкоголю), насиченого творчими заняттями, зокрема, пов'язаними з народними традиціями та обрядами, роль відповідальних сина чи дочки, які люблять своїх батьків і допомагають їм.

Збагатився ціннісний складник внутрішнього світу учнів. Вони більшою мірою стали усвідомлювати потребу в дружбі, співпраці один 3 одним, толерантності у ставленні одне до одного, 
відповідальності за своє життя й життя інших, зміцніли їхні вміння обстоювати власну позицію, зросли самостійність та асертивність.

Суттєво вдосконалилися комунікативні здібності молодших підлітків, зокрема зріс словниковий запас, покращилися вимова й інтонаційна образність мовлення, i не тільки в навчальній діяльності, а й у повсякденному спілкуванні. Розвинулися також елементи соціального інтелекту: краще розуміння співрозмовника, вміння оцінювати його за одягом, рухами, висловлюваннями. Удосконалились уміння працювати в групі, вислуховувати один одного, не перериваючи, разом виробляти мету діяльності й доводити її до завершення.

У результаті театрально-ігрової роботи в старших підлітків почіткішали уявлення про соціальні ролі громадянина, майбутні сімейні ролі, тобто розуміння вимог до чоловіка й дружини, емоційно збагатилося ставлення до осіб протилежної статі, відповідальнішим стало виконання ролей сина (дочки), онука (онучки). Поглибилось також усвідомлення підлітками необхідності підготовки до майбутньої професійної діяльності, виконання соціальної ролі трудівника. Школярі продемонстрували здатність аналізувати власні здібності, називали ширшу палітру якостей, що, на їхню думку, сприятимуть їм у майбутній трудовій діяльності.

Різноманітнішою й більш творчою стала змістова наповненість дозвілля старших підлітків. Хоча вільний час школярів зазвичай заповнюється спілкуванням з друзями, переглядом телепрограм, комп'ютерними іграми тощо, час на творчі види занять (читання художньої літератури, заняття в гуртках, зокрема драматичного напряму, образотворча, художньо-прикладна творчість та ін.) суттєво зріс - до $35 \%$.

Позитивні зрушення виявлено у ставленні старших підлітків до таких негативних звичок, як куріння, вживання алкоголю й наркотиків. Зазначимо також, що під впливом театрально-ігрових методик соціально-компетентнісного спрямування суттєво підвищилася оцінка старшими підлітками власного дозвілля. 74\% іiі учасників відповіли, що проведення власного дозвілля їм подобається, $21 \%$ - що дозвілля подобається певною мірою. Отже, можемо зробити висновок, що заповнення дозвілля різноманітними творчими заняттями, театрально-ігровою діяльністю, іншими суспільно-корисними справами позитивно впливає на почуттєво-емоційний стан дітей.

У результаті аналізу твору «Що для мене $\epsilon$ найважливішим у житті?», який писали учні, було з'ясовано, що цінності особистого 
життя (батьки, родина, життя, здоров'я, друзі) займають провідне місце в їхньому ціннісному полі - 51\%. Разом із тим більший відсоток у ціннісному полі учнів (ніж раніше) становлять моральні цінності 9,5\%, художньо-естетичні - 9\%, суспільно-громадянські - 7,2\%.

Вивчення цінностей за методикою М. Рокича [35] підтвердило, що цінності особистого життя (сім'я, здоров'я, друзі) залишаються пріоритетними для старших підлітків. Водночас такі цінності, як творчість, мистецтво в ієрархії цінностей підлітків почали займати вищі позиції, ніж це було раніше.

Робота старших підлітків над розв'язанням тестових завдань [17, с. 314-351], які дають змогу визначати ступінь розвиненості комунікативного компонента соціальної компетентності особистості, показала, що рівень конфліктності в учнів знизився, вони виявляють більшу толерантність у розв'язанні конфліктів. Можна зробити висновок, що учні демонструють готовність до більш збалансованої міжособистісної взаємодії, здатність до групової роботи, яка передбачає насамперед спрямованість на співпрацю.

Зросла мовна культура дітей, які були залучені до різних форм і видів театральної творчості. Мовлення таких учнів стало лексично багатшим, чіткішим, менш засміченим словами-паразитами. Вони продемонстрували себе уважнішими слухачами, ніж учні, які не брали участі в педагогічно організованій театрально-ігровій діяльності. Учні почали звертати більше уваги на невербальне вираження як своєї особистості, так і інших людей, що зумовило підвищення їхнього соціального інтелекту.

Діти, яких ми зарахували до групи рівня соціальної компетентності, беруть участь у громадській роботі, є лідерами в організації цікавих підліткових справ, розв'язанні учнівських проблем, цікавляться суспільно-громадськими процесами та беруть у них активну участь, уміють змістовно наповнити своє дозвілля. У міжособистісній взаємодії вони виявляють такі соціальнопсихологічні властивості своєї особистості, як асертивність, атракція, афіліація, що знаходить відображення у дружньому ставленні до ровесників, умінні працювати в групі, підтримці один одного тощо.

Зацікавленість суспільним життям у старших школярів під впливом театрально-ігрової діяльності соціально-проблемного змісту є набагато вищою, ніж у дітей, які не залучені до неї.

Щодо готовності виконувати в майбутньому роль трудівника, треба відзначити, що учні стали більш усвідомлено підходити до 
вибору своєї майбутньої професії, розуміють важливість вивчення власних здібностей та необхідності їх розвитку з метою підготовки до обраної професійної діяльності.

Сімейно-рольовий аспект соціальної компетентності старшокласників визначався за ступенем виконання ролі сина (дочки), ставленням до осіб протилежної статі, готовністю до виконання в майбутньому ролі члена подружжя.

Учні демонструють більш виражене негативне ставлення до таких суспільно та особистісно шкідливих практик, як вживання алкоголю, наркотиків, куріння. Дозвілля учнів характеризується більшою насиченістю суспільно-творчими видами занять. Вони пишуть сценарії до свят, що відбуваються в школі (класі), беруть участь у громадській діяльності, різноманітній гуртковій роботі, зокрема театрального напряму. Отже, дозвілля учнів $є$ духовно та творчо наповненим, впливаючи на становлення їхньої належної статусності, сприяючи формуванню позитивного психологічного та соціального самопочуття.

На основі проведеного аналізу робимо висновок, що під впливом виховної роботи, яка грунтувалася на організації різних форм та видів театрально-ігрової діяльності старшокласників, сформованість статусно-рольового компонента соціальної компетентності учнів стала вищою.

Коротко схарактеризуємо сформованість ціннісно-диспозиційного компонента соціальної компетентності старшокласників. Застосування методики М. Рокича [35] дало можливість з'ясувати, що провідними цінностями $\epsilon$ цінності здоров'я, наявності хороших та вірних друзів, щасливого сімейного життя. Проте вище місце в ієрархії цінностей школярів стали займати цінності суспільного визнання, свободи, щастя інших, творчості, краси природи та мистецтва. Ціннісно-диспозиційний світ старшокласників характеризується відчутнішим просоціальним вектором, що $\epsilon$ основою для налагодження гармонійних міжособистісних взаємин школярів, спрямовуючи їх на удосконалення соціального середовища, де здійснюється їхнє соціальне буття.

Розвиненість комунікативного компонента соціальної компетентності у школярів відчутно покращилась. Школярі за мімікою, жестами, поглядом, одягом вміють краще визначати рід занять людини, риси ії характеру, іï емоційну спрямованість у взаємодії з партнером, правильно встановлювати вид темпераменту як власного, так і інших людей, на основі чого вибудовувати свою лінію 
поведінки у міжособистісній взаємодії. Слід зауважити, що досить істотно покращилася мовна культура старшокласників, розширився їхній лексичний запас, зросла чіткість мовлення та збагатилась його інтонаційна забарвленість. Також підвищилась асертивність (впевненість) старшокласників, виробилися навички самопрезентації, зміцніли переконання учнів у їх необхідності для успішної самореалізації в сучасному соціумі.

Отже, отримані результати показали ефективність впливу театрально-ігрової діяльності учнів підліткового та старшого шкільного віку на становлення їхньої соціальної компетентності.

\section{Висновки}

Ускладненість сучасного суспільства, зростання числа ризиків, що постають перед його членами, зумовлюють необхідність досягнення ними соціальної компетентності, яка $\epsilon$ підгрунтям різнобічної реалізації як окремої особистості, так і повноцінного функціонування суспільного організму.

Соціальну компетентність визначено цілісним інтегративним особистісним утворенням, сукупністю соціальних знань, вмінь, цінностей, що забезпечують гармонійну взаємодію людини i суспільства (насамперед шляхом засвоєння провідних соціальних ролей, ефективного розв'язання соціально-проблемних ситуацій).

У структуру соціальної компетентності особистості включено статусно-рольовий компонент (формується під впливом вимог суспільства до своїх членів задля належного суспільного відтворення та функціонування), ціннісно-диспозиційний (формується на основі інтеріоризації особистістю соціальних цінностей та норм) та комунікативний, що включає способи соціальної взаємодії, які сприяють виконанню соціальних ролей та утвердженню соціальних цінностей.

Висвітлено потенціал театрального мистецтва у формуванні соціальної компетентності школярів та розкрито напрями театрально-педагогічної роботи з формування соціальної компетентності підлітків і старшокласників: організація театральноігрової діяльності учнів шляхом підготовки спектаклів за драматичними творами, літературними композиціями; функціонування шкільного соціально-центрованого театру, що звертається до проблем суспільства, соціально-групових питань, які $€$ безпосередньо дотичними до інтересів школярів, дають їм матеріал для роздумів про стан соціуму та власне місце в ньому; використання 
театрально-ігрових методів та прийомів у процесі вивчення навчальних дисциплін, що сприяє поглибленню компетентнісної дієвості навчальних предметів; залучення до театрально-ігрової діяльності школярів, які мають вияви дезадаптації, як спосіб сприяння їм у налагодженні нормальних відносин із соціальним середовищем.

Організація театрально-ігрової діяльності учнів підліткового та старшого шкільного віку за запропонованою нами методикою засвідчила ефективність цього засобу у формуванні соціальної компетентності школярів.

\section{Література}

1. Айхингер А., Холл В. Психодрама в детской групповой терапии / пер. с нем. Москва : Генезис, 2003. 256 с.

2. Андерсен-Уоррен М. Грейнджер Р. Драматерапия / пер. с англ. А. И. Копытина. Санкт-Петербург : Питер, 2001. 288 с.

3. Андреева И. М. Взаимосвязь театра и театрализованного сознания в социуме : дис. ... д-ра филос. наук : спец. 24.00.01 / Краснодарский гос. ун-т культуры и искусств. Краснодар, 2006. 254 с.

4. Бабосов Е. М. Общая социология : учеб. пособие для студентов вузов. 2-е изд., стер. Минск : «ТетраСистемс», 2004. 640 с.

5. Басалаев С.Н. От игровой природы театра к жизненной реальности. Мир науки, культуры, образования. 2011. № 5 (30). С. 386-387.

6. Бергер П. Л. Общество в человеке. Кравченко А. И. Социология : хрестоматия для вузов. Москва : Академ. Проект ; Екатеринбург : Деловая книга, 2002. С. 527-544.

7. Бех І. Д. Виховання особистості : навч.-методич. посіб. : у 2-х кн. Київ : Либідь, 2003. Кн. 1 : Особистісно орієнтований підхід: теоретико-технологічні засади. 280 с.

8. Богданова О. А. Создание условий формирования адекватной самооценки подростков в процессе внеучебной театральной деятельности : дис. ... канд. пед. наук : 13.00.01 / Моск. город. пед. ун-т. Москва, 2006. 198 с.

9. Гашкова Е.М. От серьёза символов к символической серьёзности (театр и театральность в XX веке). Метафизические исследования. 1997. Вып. 5. Культура. Альманах Лаборатории Метафизических Исследований при Филос. факультете СПбГУ. С. 85-95.

10. Глозман Ж. М. Общение и здоровье личности : учеб. пособие для студент. высш. учеб. заведений. Москва : Издат. центр «Академия», 2002. 208 с. 
11. Ершова А. П., Букатов В. М. Режиссура урока, общения и поведения учителя : пособие для учителя. 2-е изд., исправ. и доп. Москва : Моск. психолого-соц. ин-т : Флинта, 1998. 232 с.

12. Кон И. С. Люди и роли. Новый мир. 1970. № 12. С. 168-191.

13. Коханая O. Е. Социокультурные функции детского и молодёжного театра : автореф. дис. ... Д-ра культурологии : 24.00.01. Моск. гос. ун-т культуры и искусств. Москва, 2009. 45 с.

14. Лапина 0. А. Школьный театр в системе культуры и образования : дис. ... канд. пед. наук : 13.00 .02 / Рос. гос. пед. ун-т им. А. И. Герцена. Санкт-Петербург, 2000.168 с.

15. Лейтц Г. Психодрама: теория и практика. Классическая психодрама Я. Л. Морено / пер. с нем.; общ. ред. Е. В. Лопухиной и А. Б. Холмогоровой. Москва : Издат. группа «Прогресс», «Универс», 1994. $352 \mathrm{c}$.

16. Леонтьев Д. А. От социальных ценностей к личностным: социогенез и феноменология ценностной регуляции деятельности. URL: http://mary1982.narod.ru/leontiev.html (дата обращения : 30.09.2021).

17. Ложкін Г.В., Пов'якель Н.І. Психологія конфлікту: теорія і сучасна практика : навч. посіб. Київ : ВД «Професіонал», 2006. 416 с.

18. Майерс Д. Социальная психология. 6-е изд., перераб. и доп. Санкт-Петербург : Питер, 2002. 732 с.

19. Масол Л. М. Загальна мистецька освіта: теорія і практика : монографія. Київ : Промінь, 2006. 432 с.

20. Мухина В. С. Возрастная психология: феноменология развития, детство, отрочество : учеб. для студентов вузов. 4-е изд., стереотип. Москва : Изд. центр «Академия», 1999. 456 с.

21. Немов Р. С. Психология : в 3-х кн. Москва : Гуман. изд. центр ВЛАДОС, 1998. Кн. 2 : Психология образования : учеб. для студентов высш. учеб. заведений. 3-е изд. 608 с.

22. Орбан-Лембрик Л. Е. Соціальна психологія : у 2-х кн. Київ : Либідь, 2004. Кн. 1. : Соціальна психологія особистості і спілкування : підруч. для студентів вищ. навч. закладів. 576 с.

23. Савосина Е. А. Репрезентация социального театра как формы социальной работы с молодежью в социальных сетях. Концепт : научно-методический электронный журнал. 2016. Т. 11. C. 3281-3285. URL: http://e-koncept.ru/2016/86692.htm (дата обращения : 25.10.2021).

24. Сайкина Л. В. Технологии социально-культурной анимации в процессе коррекции девиантного поведения подростков : дис. ... 
канд. пед. наук : 13.00 .05 / Тамбов. гос. ун-т им. Г. Р. Державина. Тамбов, 2007. 213 с.

25. Сергиенко И. М. Интерактивный психологический театр: метод профилактики негативных явлений в среде молодежи : учеб. пособие. Черкассы : Изд-во ЧНУ, 2009. 100 с.

26. Синявская Я. Социальный театр как форма профилактики девиантного поведения подростков. Весна науки - 2014 : материалы межвузовской научно-практической конференции «Современные проблемы гуманитарных наук» (Санкт-Петербург, 17 апреля 2014 г.). Санкт-Петербург : Знание, ИВЭСЭП, 2014. С. 110-114.

27. Современные концепции эстетического воспитания : (Теория и практика) / отв. ред. Н. И. Киященко. Москва : ИФРАН, 1998. 301 с.

28. Станиславский К. С. Собрание сочинений : в 9-ти т. / редкол. : О. Н. Ефремов (гл. ред.) и др. Т. 2. Работа актера над собой. Часть 1. Работа над собой в творческом процессе переживания : дневник ученика. Москва : Искусство, 1989. 511 с.

29. Степаненко М. Д. Життєва компетентність особистості: концептуальні засади та соціальні виміри : автореф. дис. ... канд. філос. наук : 09.00.03 / Харків. ун-т Повітряних Сил ім. Івана Кожедуба. Харків, 2006. 19 с.

30. Театр в школе : сб. пьес / вступ. ст. В. Розентуллера. Москва : Парсифаль, 1996. 256 с.

31. Хломов К.Д. Подросток на перекрестке жизненных дорог: социализация, анализ факторов изменения среды развития. Психологическая наука и образование. 2014. № 1. URL: http://psyedu.ru/ journal/2014/1/Hlomov.phtml (Дата обращения: 25.10.2021).

32. Шахрай В.М. Теоретико-методичні засади формування соціальної компетентності учнів основної і старшої школи засобами театрального мистецтва : дис. ... докт. пед. наук : 13.00.05; 13.00 .07 / Інститут проблем виховання НАПН України. Київ, 2016. 540 с.

33. Шахрай В.М. Формування соціальної компетентності учнів основної і старшої школи засобами театрального мистецтва / Iн-т проблем виховання НАПН України. Біла Церква : Вид. Пшонківський О. В., 2016. 404 с.

34. Шпет Г. Г. Театр как искусство. Психологические исследования. 2009. Appendix 2(4). URL: http://psystudy.ru/index.php/num/ appendix2-4/59-shpet-theater-4a.html (дата обращения: 25.10.2021).

35. Rokeach M. The nature of human values. New York : Free Press, 1973. $438 \mathrm{p}$. 